\title{
2D Numerical Modeling on the Transformation Mechanism of the Braided Channel
}

\author{
Shengfa Yang and Yi Xiao * \\ National Inland Waterway Regulation Engineering Research Center, Chongqing Jiaotong University, \\ Chongqing 400074, China; ysf777@163.com \\ * Correspondence: xymttlove@163.com; Tel.: +86-023-6265-4621
}

Received: 25 July 2019; Accepted: 24 September 2019; Published: 28 September 2019

\begin{abstract}
This paper investigates the transformation mechanism between different channel patterns. A developed 2D depth-averaged numerical model is improved to take into account a bank vegetation stress term in the momentum conservation equation of flow. Then, the extended 2D model is applied to duplicate the evolution of channel pattern with variations in flow discharge, sediment supply and bank vegetation. Complex interaction among the flow discharge, sediment supply and bank vegetation leads to a transition from the braided pattern to the meandering one. Analysis of the simulation process indicates that (1) a decrease in the flow discharge and sediment supply can lead to the transition and (2) the riparian vegetation helps stabilize the cut bank and bar surface, but is not a key in the transition. The results are in agreement with the criterion proposed in the previous research, confirming the 2D numerical model's potential in predicting the transition between different channel patterns and improving understanding of the fluvial process.
\end{abstract}

Keywords: fluvial process; bank vegetation; channel pattern; 2D numerical model

\section{Introduction}

Channel pattern refers to the limited reaches of the river that can be defined as straight, meandering or braided. While long, straight rivers seldom occur in nature; meandering and braided rivers are common [1]. The transformation of channel patterns take place in response to variations in different variables, which can be grouped into four categories: (i) Dynamic flow, (ii) shape and characteristics of the channel, (iii) sediment load and (iv) bed and bank material [2]. A sound understanding of the relationship between the control variables and channel pattern is fundamental to the development of improved management strategies in braided rivers [3]. The laboratory flume experiments have shed much light on the dynamic behavior of a wide braided river to a single-thread channel [4-10]. Various criteria have been proposed on the response of channel morphology to control variables [11-14]. Quantitative inconsistencies in both the coefficients and exponents of discriminant functions have resulted from the use of different measures of slope and discharge, as well as differences in the definitions of the transition between channel patterns [15-17].

With the rapid developments of numerical and mathematics methods in fluid mechanics, multiple-mathematics models have become important tools for investigating dynamic interactions in evolving braid units. The development of physically based theories, which attempt to relate pattern and process in a predictive manner, offer improved insight into the primary variables controlling channel pattern. Models based on linearized physics-based equations [18-21] and 2D nonlinear physics-based morphological models [22-25] have been established to simulate the braided channel evolution. Cellular models [26-29], 2D and 3D flow-sediment numerical models [30-35] have been developed to model braided rivers. Although various computational studies on the formation of braided rivers are available, few preliminary numerical studies of the transformation process from the 
braided to meandering pattern are offered [36], to discuss the interactions of multiple factors, such as flow conditions, sediment characteristics and bank stability.

The primary objective of this study is to investigate the dynamic process of the transformation between different channel patterns with different control variables. The original $2 \mathrm{D}$ numerical model takes the vegetation term into the flow momentum equation, and is verified in the middle section of the Yangtze River. Subsequently, a conceptual braided channel is established in the numerical experiment, control factors as flow discharge, sediment supply and bank vegetation are considered in the simulation of the transition from the braided to the meandering channel. The proposed criteria were applied to discuss the transition process between the braided and meandering channel, the results agree well with the previous research. It demonstrates that the 2D numerical model can be applied to improve understanding of patterning processes under different scenarios.

\section{Numerical Model}

\subsection{Model Description}

The 2D numerical model incorporates the hydrodynamic, sediment transport and river morphological adjustment sub-model. It is solved in the orthogonal curvilinear grid system by using the Beam and Warming alternating-direction implicit (ADI) scheme. The sediment transport submodel includes the influence of non-uniform sediment with bed surface armoring and a correction for the direction of bed-load transport due to secondary flow and transverse bed slope. The bank erosion submodel incorporates a simple simulation method for updating bank geometry during either degradational or aggradational bed evolution. The details of the developed 2D model can be found in Xiao et al. [37], and verified in the physical meandering channel and the upstream of the Yangtze River [38].

\subsection{Consideration of the Riparian Vegetation Influence}

The significance of riparian vegetation as a control of river form and process is increasingly being recognized in fluvial research. In this study, the hydrodynamic portion of the 2D numerical model was upgraded to incorporate the effects of riparian vegetation.

The equilibrium equation for the riparian vegetation zones herein can be introduced by Ikeda and Izumi [39] in the form:

$$
\frac{\tau}{\cos \theta}=\rho g H S-D_{r}+\frac{d}{d y} \int_{0}^{H}\left(-\rho \overline{u^{\prime} v^{\prime}}\right) d z
$$

where $\tau$ is the total shear stress near the river bank $(\mathrm{Pa}) ; D_{r}$ is the vegetation stress term $(\mathrm{Pa}) ; v^{\prime}, u^{\prime}$ are the fluctuating velocity in the longitudinal and transverse direction $(\mathrm{m} / \mathrm{s})$, respectively; $S$ is the slope, $H$ is the averaged water depth $(\mathrm{m})$ and $\theta$ is the inclination of the location, often $\theta \approx 0$, Equation (1) can be reduced to:

$$
\begin{gathered}
\tau=\rho g H S-D_{r}+\frac{d}{d y} \int_{0}^{H}\left(-\rho \overline{u^{\prime} v^{\prime}}\right) d z \\
D_{r}=\frac{1}{2} \rho C_{D} \bar{u}^{2} \frac{a H}{\cos \theta} \\
\tau=\tau_{j}^{L}+\tau^{T}-D_{r} .
\end{gathered}
$$

Let $p^{v}=D_{r}$, substitute it to the momentum conservation equation of flow in the Cartesian coordinate system as:

$$
\begin{gathered}
\frac{\partial}{\partial t}\left(\rho u_{i}\right)+\frac{\partial}{\partial x_{j}}\left(\rho u_{i} u_{j}\right)=\rho f_{i}-\frac{\partial p}{\partial x_{i}}+\frac{\partial \tau_{i j}}{\partial x_{j}}-\frac{\partial p^{v}}{\partial x_{i}} \\
\frac{\partial p^{v}}{\partial x_{i}}=\frac{\partial\left(\frac{1}{2} \rho C_{D} \bar{u}^{2} \frac{a H}{\cos \theta}\right)}{\partial x_{i}}=\frac{1}{2} \rho C_{D} \frac{a H}{\cos \theta} \bar{u} u_{i} i=1,2, \\
\bar{u}=\sqrt{\sum_{i} u_{i}^{2}} \quad i=1,2
\end{gathered}
$$


where $p^{v}$ should satisfy the additional condition in all directions as: $p^{v}=\sum_{i=1}^{2}\left(\frac{\partial p^{v}}{\partial x_{i}}\right)^{2} ; \bar{u}$ is the depth-averaged flow velocity $(\mathrm{m} / \mathrm{s}) ; u_{i}$ is the flow velocity in the $i$-direction $(\mathrm{m} / \mathrm{s}) ; a$ is the vegetation density $\left(\mathrm{m}^{-1}\right)$, defined as $a=d /\left(l_{x} l_{y}\right), d$ is the radius of the vegetation $(\mathrm{m})$ and $l_{x}$ and $l_{y}$ are the distance of vegetation in the longitudinal and transverse directions $(\mathrm{m})$.

$C_{D}$ is the drag coefficient of vegetation. Consider the influence range of the vegetation coefficient, let $C_{D}=1.5$ when the vegetation zones near the river bank [39]; if the zones of vegetation are in the river channel, we assumed the influence of vegetation was proportionate to the distance from the channel center in the form:

$$
\begin{array}{cc}
C_{D}=0 & x=l \\
C_{D}=1.5-1.5 x / l & 0<x<l \\
C_{D}=1.5 & x=0
\end{array}
$$

where $l$ is the distance from the river bank to the channel center $(\mathrm{m}) ; x$ is the distance from the computed point to the river bank (m).

In this study, we substituted Equations (4) and (5) to the 2D depth-averaged momentum conservation equation of flow in the orthogonal curvilinear coordinate system as follows:

$$
\begin{gathered}
\frac{\partial q}{\partial t}+\beta\left(\frac{1}{J} \frac{\partial\left(h_{2} q U\right)}{\partial \xi}+\frac{1}{J} \frac{\partial\left(h_{1} p U\right)}{\partial \eta}-\frac{p V}{J} \frac{\partial h_{2}}{\partial \xi}+\frac{q V}{J} \frac{\partial h_{1}}{\partial \eta}\right)-f p+\frac{g H}{h_{1}} \frac{\partial Z}{\partial \xi}+\frac{q g|\bar{q}|}{(C H)^{2}}=\frac{v_{e} H}{h_{1}} \frac{\partial E}{\partial \xi}-\frac{v_{e} H}{h_{2}} \frac{\partial F}{\partial \eta}+\frac{1}{J} \frac{\partial\left(h_{2} D_{11}\right)}{\partial \xi} \\
+\frac{1}{J} \frac{\partial\left(h_{1} D_{12}\right)}{\partial \eta}+\frac{1}{J} \frac{\partial h_{1}}{\partial \eta} D_{12}-\frac{1}{J} \frac{\partial h_{2}}{\partial \xi} D_{22}-\frac{1}{2} \rho C_{D} \frac{a H}{\cos \theta} \sqrt{U^{2}+V^{2}} \frac{y_{\eta} h_{1} U-y_{\xi} h_{2} V}{J} \\
\frac{\partial p}{\partial t}+\beta\left(\frac{1}{J} \frac{\partial\left(h_{2} q V\right)}{\partial \xi}+\frac{1}{J} \frac{\partial\left(h_{1} p V\right)}{\partial \eta}+\frac{p U}{J} \frac{\partial h_{2}}{\partial \xi}-\frac{q U}{J} \frac{\partial h_{1}}{\partial \eta}\right)+f q+\frac{g H}{h_{2}} \frac{\partial Z}{\partial \eta}+\frac{p g|\bar{q}|}{(C H)^{2}}=\frac{v_{e} H}{h_{2}} \frac{\partial E}{\partial \eta}+\frac{v_{e} H}{h_{1}} \frac{\partial F}{\partial \xi}+\frac{1}{J} \frac{\partial\left(h_{2} D_{12}\right)}{\partial \xi} \\
+\frac{1}{J} \frac{\partial\left(h_{1} D_{22}\right)}{\partial \eta}-\frac{1}{J} \frac{\partial h_{1}}{\partial \eta} D_{11}+\frac{1}{J} \frac{\partial h_{2}}{\partial \xi} D_{12}-\frac{1}{2} \rho C_{D} \frac{a H}{\cos \theta} \sqrt{U^{2}+V^{2}} \frac{x_{\xi} h_{2} V-x_{\eta} h_{1} U}{J}
\end{gathered}
$$

where $h_{1}$ and $h_{2}$ are the lame coefficients in the $\xi$ and $\eta$ direction, respectively; $U$ and $V$ are the depth-averaged flow velocity components in the $\xi$ and $\eta$ direction; the unit discharge vector is $\bar{q}=(q, p)=(U H, V H) ; z$ is the water level relative to the reference plane; $\beta$ is the correction factor for non-uniformity of the vertical velocity profile; $f$ is the Coriolis parameter, which was neglected in this study; $g$ is the gravitational acceleration; $C$ is the Chezy coefficient; $v_{e}$ is the depth mean effective vortex viscosity, $z_{s}$ and $z_{b}$ are the dependent water levels at the water surface and channel bed, respectively.

\subsection{Verification}

The extended 2D numerical model was applied to a $102 \mathrm{~km}$ long, 'S' shaped channel section in the middle Yangtze River, and the bank along the river from Shashi to Shishou is protected by the riparian vegetation. An orthogonal curvilinear coordinate system was applied with a total of $600 \times 115$ grids in the computational domain and a time interval of $t=8 \mathrm{~s}$ (Figure 1). The angles between the $\xi$ and $\eta$ grid lines were $88^{\circ}$ and $-92^{\circ}$, except for some grids close to the banks. The grid spacing was $100-180 \mathrm{~m}$ in the $\xi$ direction and $35-45 \mathrm{~m}$ in the $\eta$ direction. Observed daily water discharge and sediment load at the inlet were used as boundary conditions and bed contour maps dated September 2002 was the initial topography [40]. Calculation of suspended load was divided to eight group ranging from 0.005 to $1 \mathrm{~mm}$ in diameter (Table 1). The sediment gradation in bed materials (Table 2), transport capacity for various size groups, and river topography were adjusted every $24 \mathrm{~h}$. The thickness of active layers were $L_{a}=15 \mathrm{~m}$. A real time period of two years was simulated, and the calculated results of flow velocity, water stage and morphological changes were compared with the measured data. 


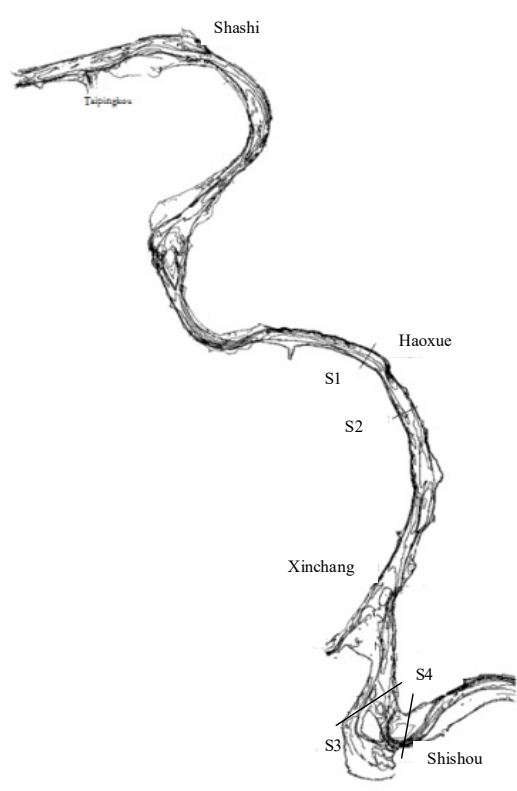

(a)

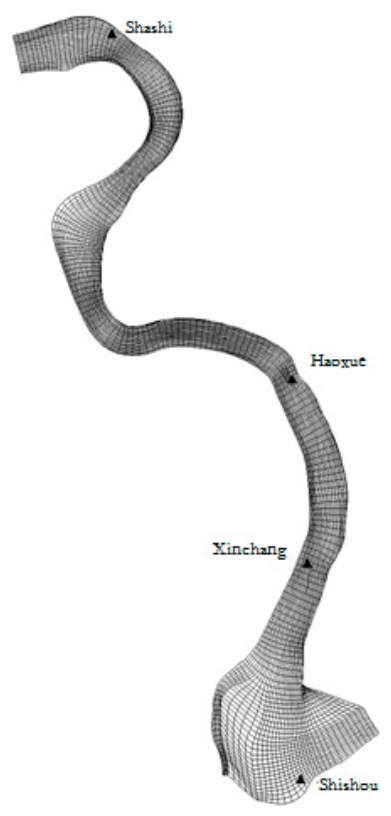

(b)

Figure 1. Layout of the field study reach section and its computational mesh. (a) layout of the study river section; (b) computational mesh.

Table 1. The fraction of suspended load being simulated.

\begin{tabular}{ccccccccc}
\hline No. & $\mathbf{1}$ & $\mathbf{2}$ & $\mathbf{3}$ & $\mathbf{4}$ & $\mathbf{5}$ & $\mathbf{6}$ & $\mathbf{7}$ & $\mathbf{8}$ \\
\hline Size $(\mathrm{mm})$ & 0.004 & 0.008 & 0.016 & 0.031 & 0.062 & 0.125 & 0.25 & 0.5 \\
Proportion & 30 & 12.7 & 13.4 & 14.6 & 13.1 & 8.2 & 6.5 & 1.5 \\
\hline
\end{tabular}

Table 2. The fraction of bed material.

\begin{tabular}{cccccccccccc}
\hline No. & \multicolumn{1}{c}{ Group Percentage of Bed Materials } & \multicolumn{1}{c}{$D_{\mathbf{5 0}}(\mathbf{m m})$} & Year \\
\hline & 0.004 & 0.008 & 0.016 & 0.03 & 0.062 & 0.125 & 0.25 & 0.5 & 1 & & \\
$\%$ & 0 & 0 & 0 & 0.1 & 1.1 & 13.2 & 55.3 & 30 & 0.3 & 0.193 & 2002 \\
\hline
\end{tabular}

Comparison of observed and calculated cross-sectional profile of depth averaged stream-wise velocity for various discharges in November 2003 is shown in Figure 2, calculated depth-averaged velocities were consistent with the observed asymmetrical velocity patterns, and the relative error near the bank vegetation area was below $6 \%$. Figure 3 shows the comparison of the measured and calculated water stages at two hydrometric stations during September 2002-July 2004, which indicate good agreements between simulations and measurements. 


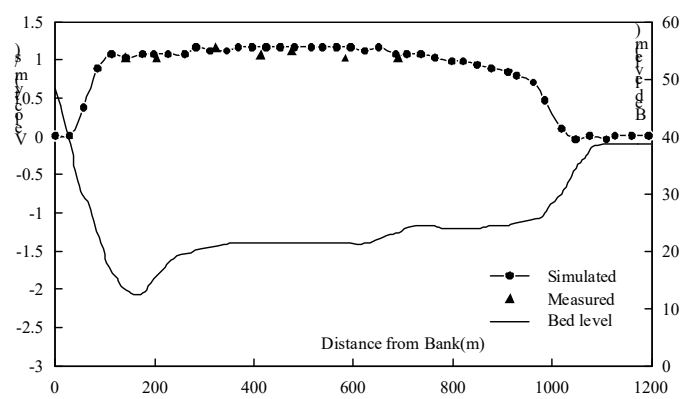

(a)

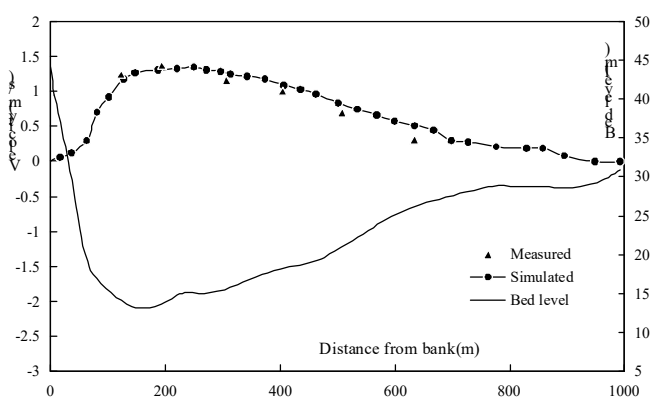

(b)

Figure 2. Measured and calculated cross-sectional profiles of depth-averaged velocity. (a) cross section S1; (b) cross section S2.

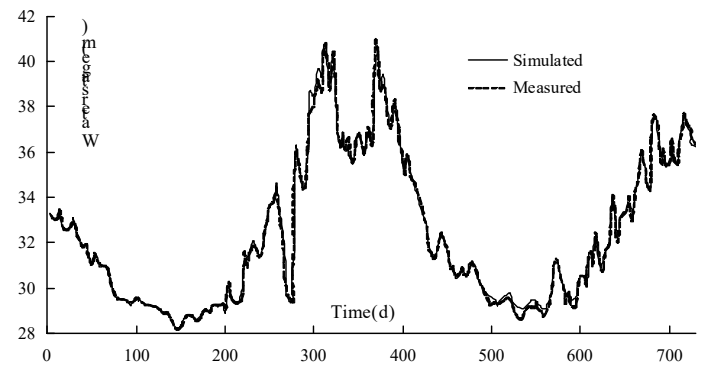

(a)

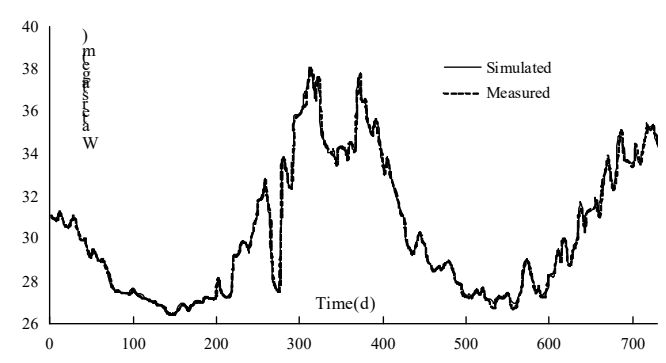

(b)

Figure 3. Comparison of the water stages at two control stations. (a) Shashi station; (b) Xinchang station.

Table 3 lists the measured and calculated total amount of deposition or scour. It indicates that the largest discrepancy between observed and calculated of results was found in the entrance section from Taipingkou-shashi, possibly due to the uncertainties introduced by the initial and boundary conditions. Figure 4 is a comparison between the calculated and measured scour and deposition depths. It can be seen that except the entrance section, the predicted pattern of scour and deposition agreed well with observations if reliable information of bank material, riparian vegetation and bed material size could be obtained. A comparison of changes of the bed level at the typical cross sections shows that as time progressed, the pattern of the cross sections tended to the measurements with acceptable ranges of error (Figure 5).

Table 3. Measured and calculated volumes of deposition (+) or scour (-).

\begin{tabular}{ccccc}
\hline River Section & $\begin{array}{c}\text { Total Distance } \\
(\mathbf{k m})\end{array}$ & $\begin{array}{c}\text { Section Length } \\
\mathbf{( k m )}\end{array}$ & $\begin{array}{c}\text { Measured } \\
\left(\mathbf{1 0} \mathbf{m}^{\mathbf{3}} \mathbf{)}\right.\end{array}$ & $\begin{array}{c}\text { Calculated } \\
\mathbf{( 1 0}^{\mathbf{6}} \mathbf{~ m}^{\mathbf{3}} \mathbf{)}\end{array}$ \\
\hline Taipingkou-Shashi & 8.47 & 8.47 & -827.26 & -1185.91 \\
Shashi-Haoxue & 58.65 & 50.19 & -1705.39 & -1730.82 \\
Haoxue-Xinchang & 73.62 & 14.96 & -1353.62 & -924.21 \\
Xinchang-Shishou & 93.38 & 19.76 & -1508.87 & -1719.86 \\
\hline
\end{tabular}




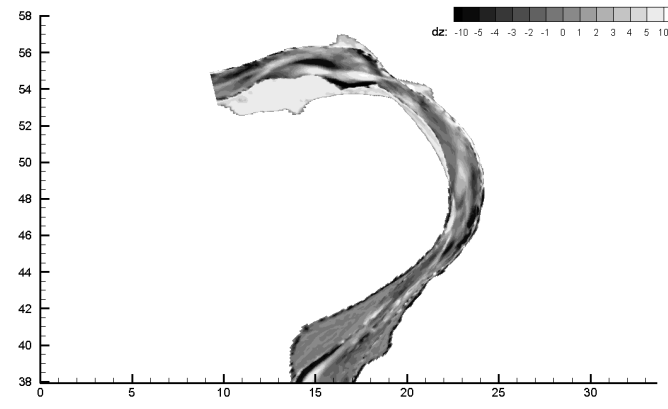

(a)

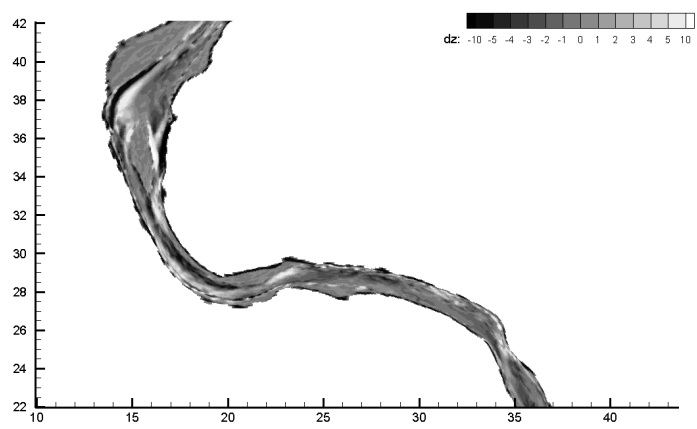

(c)

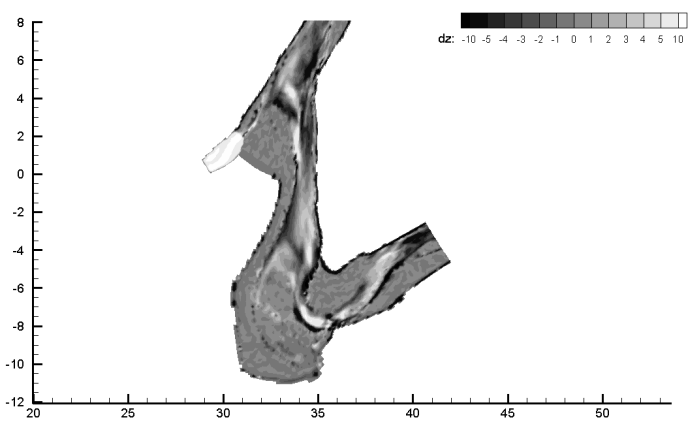

(e)

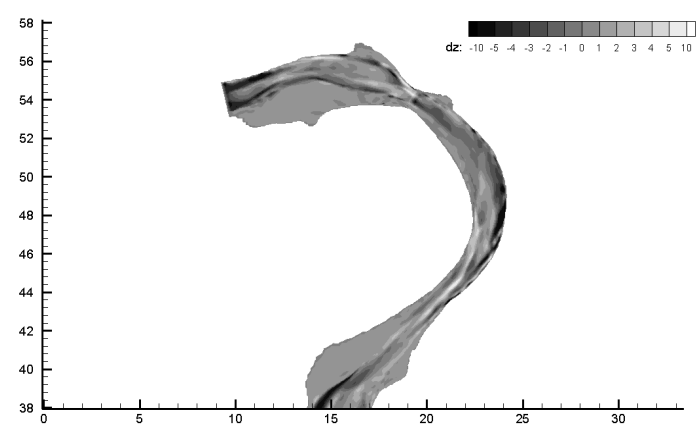

(b)

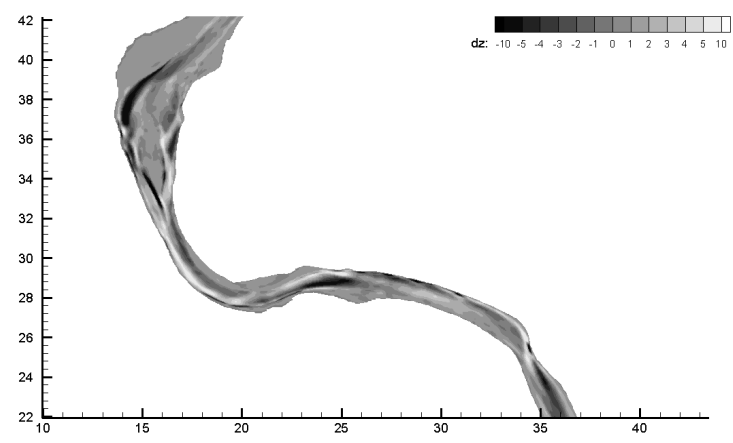

(d)

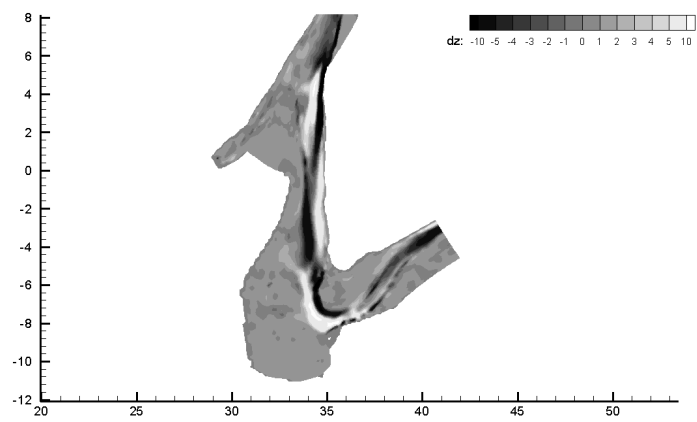

(f)

Figure 4. Calculated and measured scour or deposition depths of reach section (x: the distance from the $\mathrm{x}$-direction $/ \mathrm{m}$; $\mathrm{y}$ : the distance from the $\mathrm{y}$-direction $/ \mathrm{m}$; dz: the bed level changes $/ \mathrm{m})$. (a) Measured; (b) calculated; (c) measured; (d) calculated; (e) measured and (f) calculated.

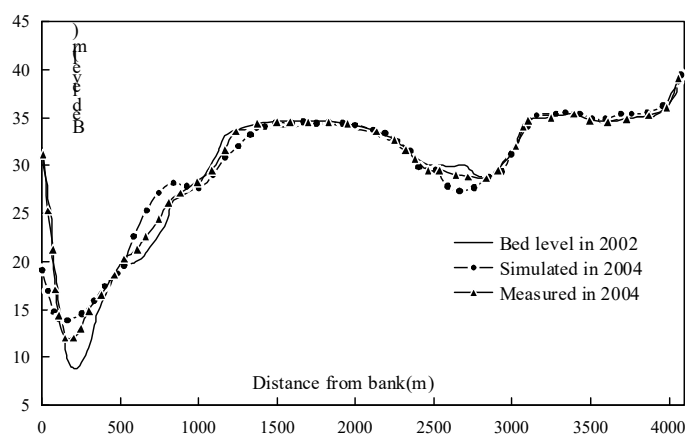

(a)

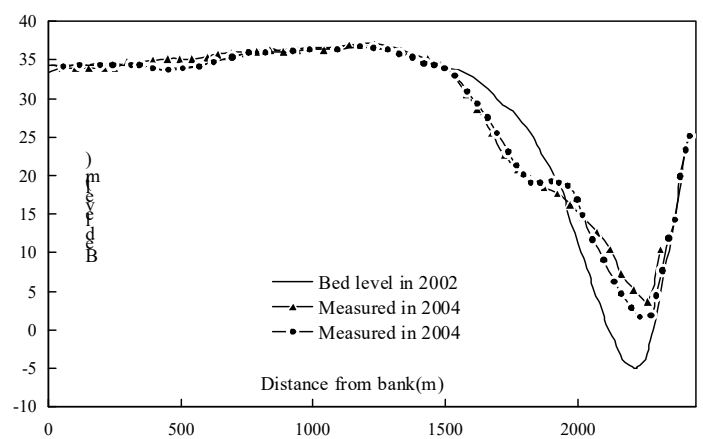

(b)

Figure 5. Measured and calculated bed deformation at various typical cross sections. (a) cross section S3 and (b) cross section S4. 


\section{Numerical Modeling on the Transformation of Braided and Meandering Channel}

\subsection{Formation of the Braided Channel}

The conceptual channel was 10,000 m long and $300 \mathrm{~m}$ wide, and the grid system of $400 \times 80$ nodes was generated. The initial bed was flat with a $0.4 \%$ slope, the medium grain size of the sediment supply and the bed material was $0.1 \mathrm{~mm}$. The inlet water discharge and sediment feed rate are provided in Table 4, and the outlet water level was constant during the simulation, the repose of the sediment $\varphi^{\prime}=$ 14 , and the lateral erosion coefficient of the bank as $C=0.011$. The computational time interval $\Delta t=6 \mathrm{~s}$, and the simulation time period was 720 days.

Table 4. The experimental conditions.

\begin{tabular}{|c|c|c|c|c|}
\hline Time Period & $\begin{array}{l}\text { Time } \\
\text { (d) }\end{array}$ & $\begin{array}{l}\text { Discharge } \\
\left(\mathrm{m}^{3} / \mathrm{s}\right)\end{array}$ & $\begin{array}{l}\text { The Medium Grain Size } \\
\text { (mm) }\end{array}$ & $\begin{array}{l}\text { Sediment Supply } \\
\qquad\left(\mathrm{kg} / \mathrm{m}^{3}\right)\end{array}$ \\
\hline 1 & 360 & 150 & 0.1 & 1 \\
\hline 2 & 360 & 300 & 0.1 & 5 \\
\hline
\end{tabular}

Figure 6 depicts an unstable braided river pattern after 720 days. Two control factors contributed to the formation of the braided channel: Large and sudden variation in discharge resulted in broadened channel cross-sections; large sediment supply led to aggradation up and down in the upper section of the stream and the initially symmetric inflow became almost asymmetrical and formed point bars or migrating central bars. It illustrated that a fluctuation in the controls would induce changes of the braided channel pattern to another pattern.

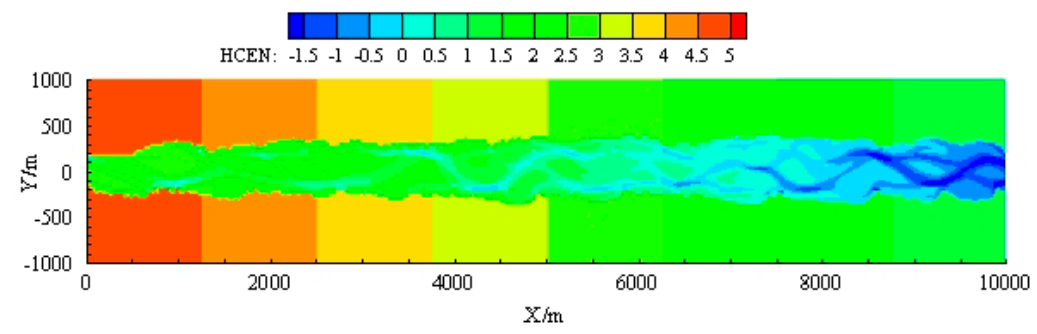

Figure 6. Layout of the conceptual channel after 720 days.

\subsection{The Transformation of the Braided Channel under Control Variables}

Based on the simulated braided river, four numerical experiments were performed including the effect of water discharge, sediment supply and bank vegetation. The experimental conditions can be seen in Table 5.

Table 5. The experimental conditions.

\begin{tabular}{ccccc}
\hline No. & $\begin{array}{c}\text { Flow Discharge } \\
\left(\mathbf{m}^{\mathbf{3}} / \mathbf{s}\right)\end{array}$ & $\begin{array}{c}\text { Sediment Supply } \\
\left(\mathbf{k g} / \mathbf{m}^{\mathbf{3}}\right)\end{array}$ & Bank Vegetation & $\begin{array}{c}\text { Time } \\
\mathbf{( d )}\end{array}$ \\
\hline 1 & 150 & 5 & Yes & 600 \\
2 & 300 & 1 & No & 600 \\
3 & 300 & 5 & No & 600 \\
4 & 150 & 1 & Yes & 600 \\
\hline
\end{tabular}

Figure 7 depicts the final planform of the braided river for runs No. 1, 2 and 3. In run No. 1, reduction of the discharge led to a weak sediment transport capacity, sedimentation took place in the branch channel and a new main channel was formed in the upper section. With time processes, aggradation resulted in higher bed elevations above the initial bed profile in the upstream, led to an 
increase of the stream power in the downstream and a broad, island braided channel was formed (Figure 7a). The braided channel in run No. 2 also transferred to a meandering channel in the upstream with different mechanisms compared with run No. 1: A reduction of sediment load resulted in less aggradation and bed scour in the upper part, and might be a key factor in the formation of a straight channel pattern with no island-bars in the downstream (Figure 7b). Figure 7c shows that bank vegetation enhanced the strength of banks, stabilized the channel, held on the sediment and the plan view seemed like that of run No. 2. As shown in Figure 7d, the planform of run No. 4 was obtained by the contribution of the influence of discharge, sediment supply and bank vegetation. It can be seen that the channel transformed to a single thread channel pattern differing from the other three numerical experiments, especially in the downstream; the reach downstream was sketched, where the wetted and active branches were marked off.

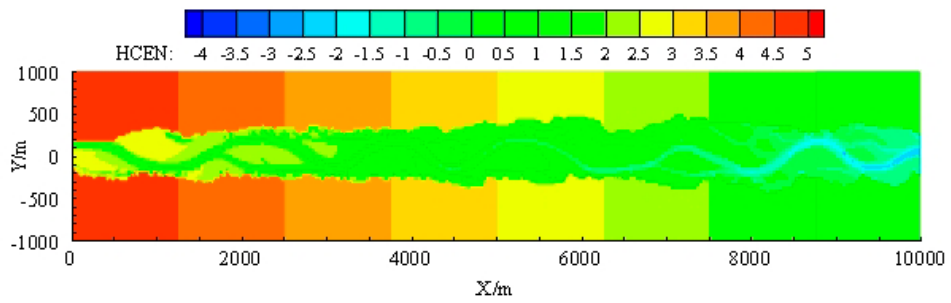

(a) Run No.1.

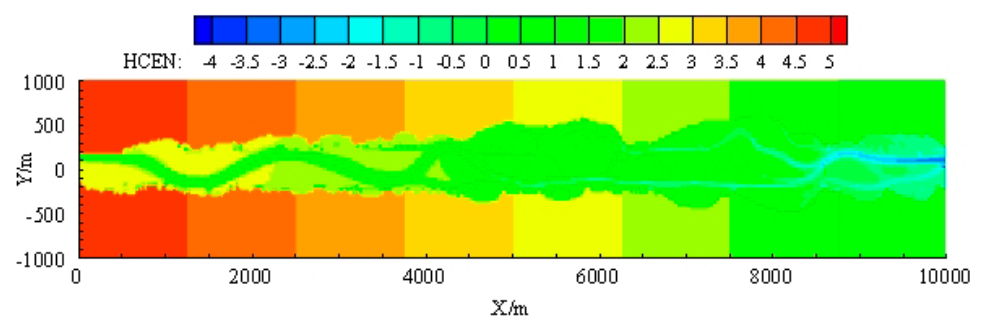

(b) Run No.2.

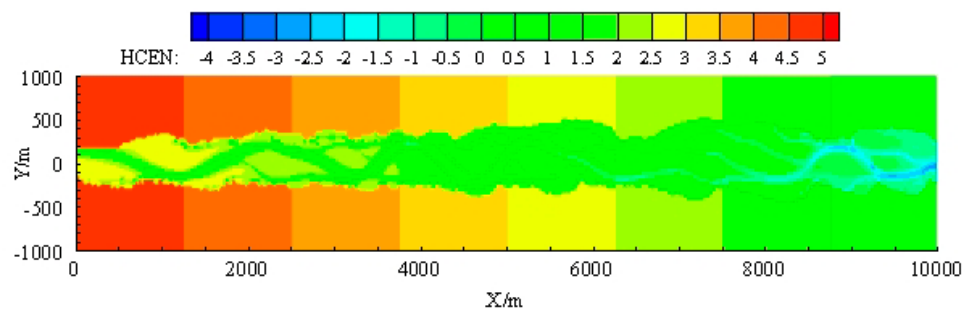

(c) Run No.3.

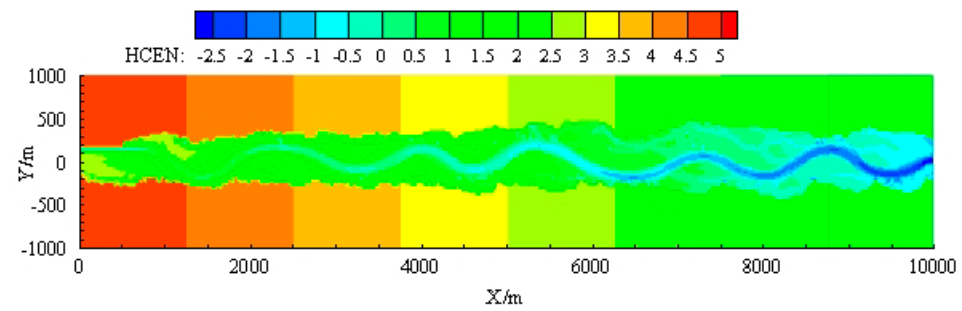

(d) Run No.4.

Figure 7. Layout of the experimental channel after 600 days (HCEN: Bed level/m). (a) Run No. 1; (b) Run No. 2; (c) Run No. 3; (d) Run No. 4. 


\section{Discussion}

\subsection{The Cross Section Change}

Figure 8 shows the comparison of the bed deformations between runs No. 1-3 and the initial braided river at the $6000 \mathrm{~m}$ cross section. As decreasing the discharge and sediment load respectively in run No.1 and 2, the main channel shifted to the right bank as the sand bars growing at the left bank; the shape of the cross section transit from " $W$ " to " $U$ "; the width ratio was lower and the depth of the channel in run No. 3 was deeper than that of run No. 1-2, it illustrated that the vegetation could increase tensile and shear strength, gave adequate time and conditions for development, such stabilization allows the existence of relatively steep cut banks, and might hinder the lateral migration of channels [41].

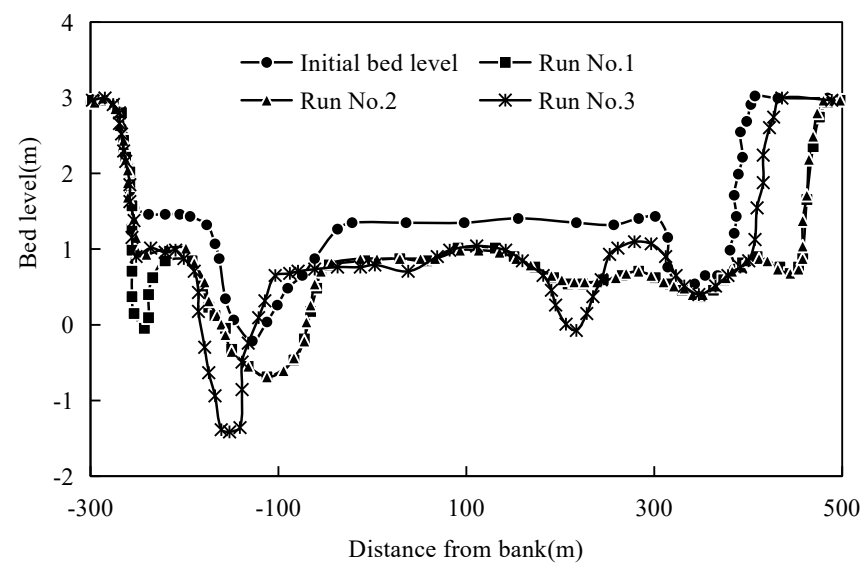

Figure 8. Comparison of bed deformation at the $6000 \mathrm{~m}$ cross-section.

\subsection{The Channel Planform Change}

The quantified parameters characterizing run No. 1-4 were obtained in Table 3. "Braided -channel ratio" B was used to describe the development of multiple channels from a channel belt as follows [42]:

$$
B=L_{c t o t} / L_{c \max }
$$

where $L_{c t o t}$ is the sum of the mid-channel lengths of all the segments of primary channels in a reach and $L_{c \max }$ is the mid-channel length of the same channel.

Table 6 shows the braiding and meandering parameters for run No. 1-4. Due to the similar plan view in run No. 2 and run No. 3, one could see the values of the sinuosity $(P)$ and braided-channel ratio (B) tended to correlate negatively with the reduction of breaches. Figure 9 presents the sketch of the braided reach for the initial and run 1, 2 and 4. Theoretically, if a reach has only a single channel, with no braids, the braided-channel ratio (B) would approach 1 as the sinuosity $(\mathrm{P})$ of the river section has the minimum value of unity.

Table 6. The parameters of the braided reach.

\begin{tabular}{cccc}
\hline No. & Number of Breaches & Braided-Channel Ratio (B) & Sinuosity (P) \\
\hline Run No. 1 & 6 & 2.11 & 1.06 \\
Run No. 2 & 5 & 1.9 & 1.00 \\
Run No. 3 & 4 & 1.97 & 1.01 \\
Run No. 4 & 2 & 1.22 & 1.35 \\
\hline
\end{tabular}




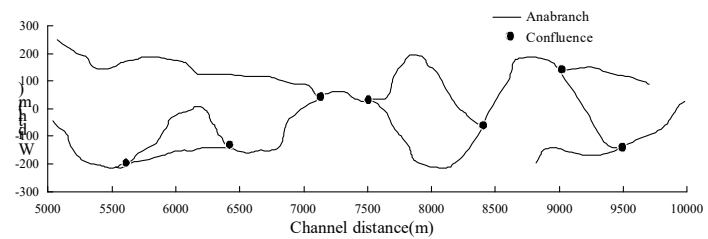

(a)

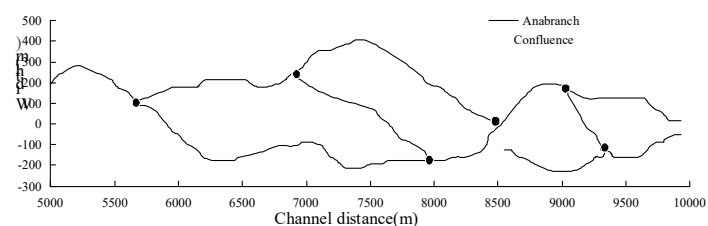

(c)

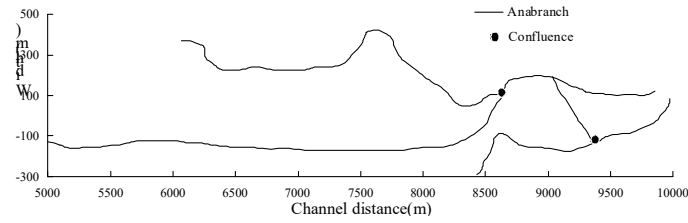

(b)

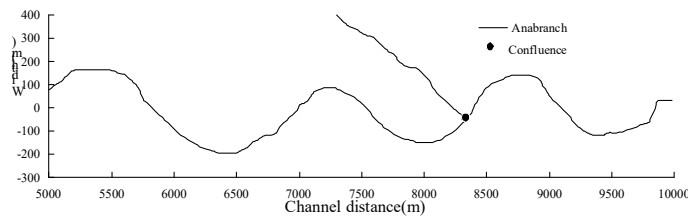

(d)

Figure 9. Sketch of the braided reach for initial and run 1-4. (a) Initial reach; (b) run 1; (c) run 2 and (d) run 4.

A large portion of branches exhibited morphological activity, with seven branches in initial reach as shown in Figure 9a, the number of branches was reduced to two in run No. 4 while the channel pattern became the meandering (Figure 9d). The results reflected that the value of $P$ would decrease with the channel belts intersect each other, and the channel belts developing along the single-channel, meandering arm had higher sinuosity. The flow field of run No. 4 was plotted in Figure 10, including the velocity and bed elevation; it can be seen that reduction of the inlet discharge and sediment supply led to a meandering flow path. The results demonstrate that the discharge and sediment supply played a significant role in the transformation mechanism of channel patterns, which agreed qualitatively with the previous work on this topic [10].

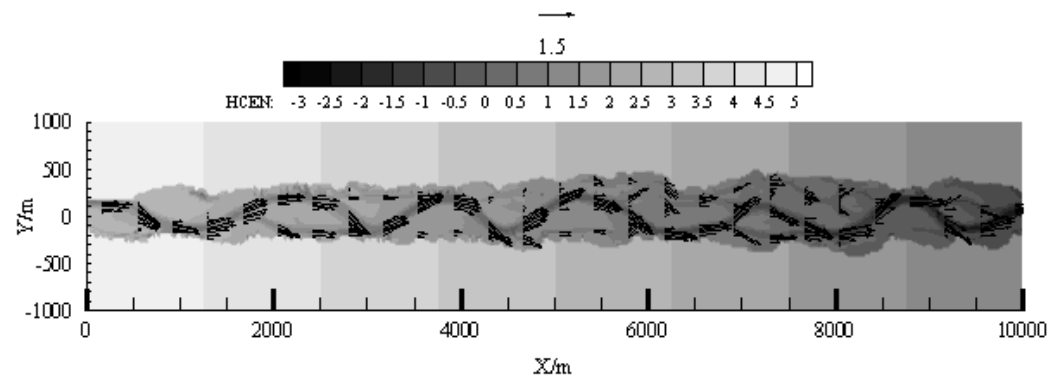

(a) $\mathrm{T}=300 \mathrm{~d}$

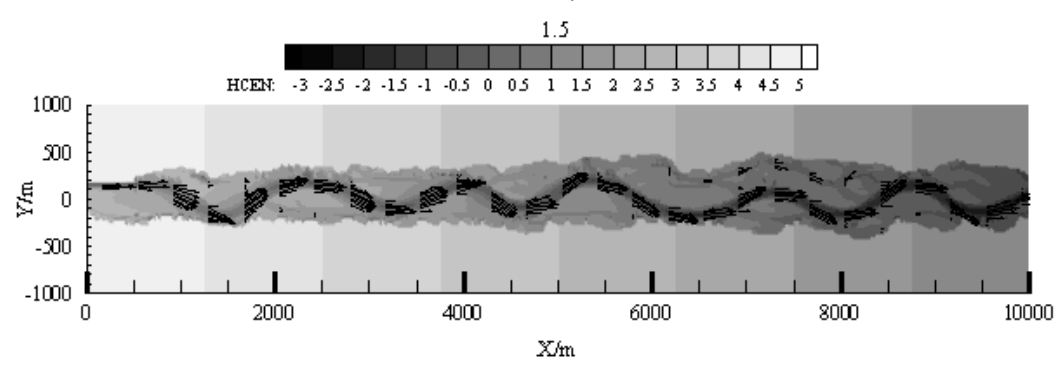

(b) $\mathrm{T}=300 \mathrm{~d}$

Figure 10. Temporal changes in flow field including velocity and bed elevation of Run No. 4 . (a) $\mathrm{T}=300 \mathrm{~d}$ and (b) $\mathrm{T}=300 \mathrm{~d}$. 


\subsection{Comparison with the Empirical Dimensionless Braiding Criterion}

Just over 50 years ago Leopold and Wolman [4] published their classic analysis of alluvial river patterns. The number of channel classification schemes increased rapidly in the following decades. The single most cited component of Leopold and Wolman is the empirical expression for the meandering-braiding threshold slope, $S^{*}$ :

$$
S^{*}=0.0125 \times Q^{-0.44},
$$

where $Q$ is the bankfull discharge $\left(\mathrm{m}^{3} / \mathrm{s}\right)$. Channel pattern is determined at least in part by both the rate and mode of sediment transport, an obvious shortcoming of Equation (9) is the absence of bed material size. Henderson [43] reanalyzed the Leopold and Wolman data and derived an equivalent expression:

$$
S^{*}=0.52 \cdot D_{50}^{1.14} \times Q^{0.44}
$$

where $D_{50}$ is the median bed surface grain size $(\mathrm{m})$. Equation (10) can be expressed using the dimensionless discharge defined by Parker [44]. The dimensionless discharge, $Q^{*}$, is given by:

$$
Q^{*}=\frac{Q}{D_{50}^{2} \sqrt{(\mathrm{s}-1) g D_{50}}}
$$

where $s$ is the specific gravity of the sediment grains. Millar [45] found that for channels where the relative bank strength does not change appreciably with the channel size, and then combined regime theory with a linear stability model to generate a morphodynamic power functions that describe the threshold slope as a function of $Q$ :

$$
S^{*}=0.00957 \mu^{\prime} Q^{*-0.25}
$$

where $\mu^{\prime}$ is the dimensionless relative bank strength given by the ratio of the critical shear stress for entrainment of the channel banks to the critical shear stress for the channel bed.

Figure 11 shows the temporal changes of the braiding criterion under four different simulation conditions. It can been seen that the data of run No. 1-3 were located in the upper bound for the braided channels, and run No. 4 data was in the lower bound for braided stream. It indicates that the relative bank strength strongly influenced channel geometry, and so for channels where the banks were more resistant than the bed, because of vegetation, we could expect a single-thread channel to persist in a region where braiding would otherwise be expected to occur [46].

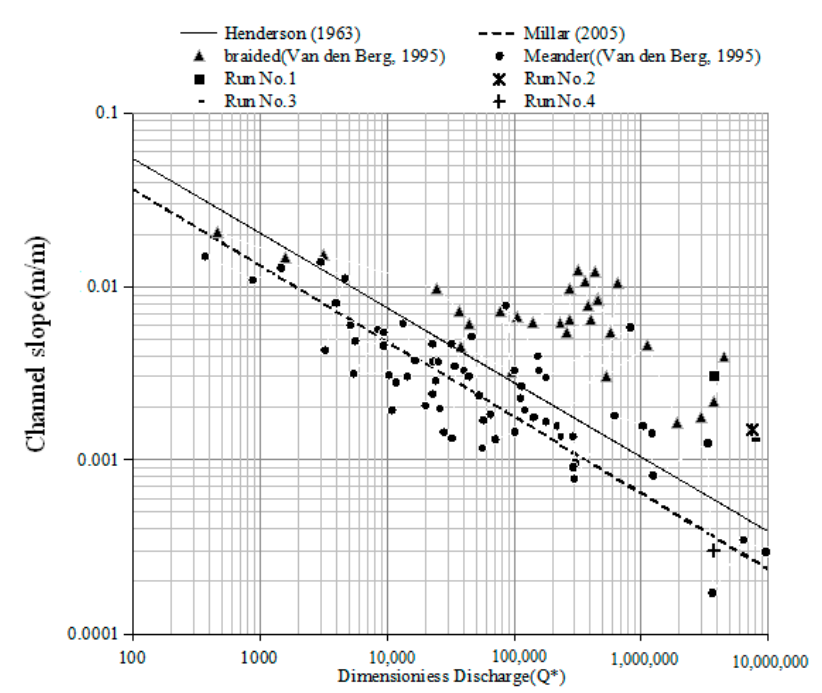

Figure 11. Dimensionless braid thresholds with the numerical experiment data. 


\section{Conclusions}

This paper presented research on the transformation mechanisms from a braided to meandering pattern by a numerical approach. A 2D depth-averaged hydrodynamic model for hydrodynamic, sediment transport and river morphological adjustment was applied in the numerical experiment. A conceptual braided channel and its transformation with different control factors were simulated to study the mechanics of fluvial process. It demonstrated that the tendency of the research on the mechanisms of fluvial processes might be regarded as a combination of the theoretical study with numerical models in future. Further studies are needed to research the fundamental equation that governs the evolution of alluvial river, which has not been fully understood to ensure the availability of the numerical model.

Author Contributions: Numerical model and experiment, S.Y. and Y.X.; analysis and manuscript preparation, S.Y. and Y.X.

Funding: This research was founded by [the National Natural Science Foundation of China] grant number [51679020].

Acknowledgments: We greatly appreciate anonymous reviewer's constructive comments which helped to improve the quality of our manuscript.

Conflicts of Interest: The authors declare no conflict of interest.

\section{Abbreviations}

\begin{tabular}{|c|c|}
\hline$\tau_{i j}$ & The shear-stress tensor \\
\hline$\tau$ & The total shear stress near the river bank \\
\hline$S$ & The slope of the water surface \\
\hline$u, v$ & The time-averaged flow velocity components in the Cartesian coordinate system \\
\hline$a$ & The vegetation density \\
\hline$l_{x}, l_{y}$ & The distance of vegetation in the longitudinal and transverse direction \\
\hline$\xi, \eta$ & The orthogonal curvilinear coordinates \\
\hline$h_{1}, h_{2}$ & The Lamé coefficients \\
\hline$J$ & The Jacobian of the transformation $J=h_{1} h_{2}$ \\
\hline Z & The water level relative to the reference plane \\
\hline$H$ & The averaged water depth \\
\hline$U, V$ & The depth-averaged velocity components in the $\xi$ and $\eta$ directions \\
\hline$\beta$ & The correction factor for the non-uniformity of the vertical velocity \\
\hline$f$ & The Coriolis parameter \\
\hline$g$ & The gravitational acceleration \\
\hline C & The Chezy coefficient \\
\hline$v_{\mathrm{e}}$ & The depth mean effective vortex viscosity \\
\hline$D_{11}, D_{12}, D_{21}, D_{22}$ & The depth-averaged dispersion stress terms \\
\hline$z_{s}, z_{b}$ & The dependent water levels for the water surface and channel bed \\
\hline$\theta$ & The inclination of the location \\
\hline$D_{r}$ & The vegetation stress term \\
\hline$k$ & von Karman constant \\
\hline$\Delta t$ & The time increment \\
\hline B & The "braided-channel ratio" \\
\hline$L_{\text {ctot }}$ & The sum of the mid-channel lengths of all the segments of primary channels in a reach \\
\hline$L_{c \max }$ & The mid-channel length of the same channel \\
\hline$S^{*}$ & The meandering-braiding threshold slope \\
\hline$Q$ & The bankfull discharge \\
\hline$Q^{*}$ & The dimensionless discharge \\
\hline$D_{50}$ & The median grain size \\
\hline
\end{tabular}




\section{References}

1. Richardson, W.R.; Thorne, C.R. Multiple thread flow and channel bifurcation in a braided river: Brahmaputra-jamuna river, Bangladesh. Geomorphology 2001, 38, 185-196. [CrossRef]

2. Biedenharn, D.S.; Watson, C.C.; Thorne, C.R. Fundaments of fluvial geomorphology. In Sediment Engineering: Processes, Measurements. Modelling and Practice; Garcia, M.H., Ed.; ASCE: New York, NY, USA, 2008; pp. 355-386.

3. Nicholas, A.P. Modelling bedload yield in braided gravel bed rivers. Geomorphology 2000, 36, 89-106. [CrossRef]

4. Leopold Luna, B.; Wolman, M. Gordon. River Channel Patterns: Braided, Meandering and Straight; U.S. Government Printing Office: Washington, DC, USA, 1957.

5. Acker, P.T.; Charlton, F.G. The geometry of small meandering streams. Proc. Inst. Civil Eng. 1971, 172, 289-317.

6. Schumm, S.A.; Khan, H.R. Experimental study of channel patterns. Geol. Soc. Am. Bull. 1972, 83, $1755-1770$. [CrossRef]

7. Ikeda, H. A study of the formation of sand bars in an experimental flume. Geogr. Rev. Jpn. 1973, 46, 435-452. [CrossRef]

8. Ikeda, H. On the bed configuration in alluvial channels; their types and condition of formation with reference to bars. Geogr. Rev. Jpn. 1975, 48, 712-730. [CrossRef]

9. Ashmore, P.E. Laboratory modeling of gravel braided stream morphology. Earth Surf. Process. Landf. 1982, 7, 201-225. [CrossRef]

10. Ashmore, P.E. How do gravel-bed rivers braid? Can. J. Earth Sci. 1991, 28, 326-341. [CrossRef]

11. Gill, M.K. Erosion of sand beds around spur dikes. J. Hydraul. Div. 1972, 98, 1587-1602.

12. Klingeman, P.C.; Kehe, S.M.; Owusu, Y.A. Steambank Erosion Protection and Channel Scour Manipulation Using Rockfill Dikes and Gabions; Technical Report; Water Resources Research Institute: Corvallis, OR, USA, 1984.

13. Kuhnle, R.A.; Alonso, C.; Shields, F.D. Geometry of scour holes associated with 90 spur dikes. J. Hydraul. Eng. 1999, 125, 972-978. [CrossRef]

14. Eaton, B.C.; Millar, R.G.; Davidson, S. Channel patterns: Braided, anabranching, and single-thread. Geomorphology 2010, 120, 353-364. [CrossRef]

15. Van den Berg, J.H. Prediction of alluvial channel pattern of perennial rivers. Geomorphology 1995, 12, $259-279$. [CrossRef]

16. Alabyan, A.M.; Chalov, R.S. Types of river channel patterns and their natural controls. Earth Surf. Process. Landf. 1998, 23, 467-474. [CrossRef]

17. Beechie, T.J.; Liermann, M.; Pollock, M.M.; Baker, S.; Davies, J. Channel pattern and river-floodplain dynamics in forested mountain river systems. Geomorphology 2006, 78, 124-141. [CrossRef]

18. Ikeda, S.; Parker, G.; Sawai, K. Bend theory of river meanders, 1, Linear development. J. Fluid Mech. 1981, 112, 363-377. [CrossRef]

19. Johannesson, H.; Parker, G. Linear theory of river meanders. Water Resour. Monogr. 1989, 12, $181-213$.

20. Zolezzi, G.; Seminara, G. Downstream and upstream influence in river meandering. Part1: General theory and application to overdeepening. J. Fluid Mech. 2001, 438, 183-211. [CrossRef]

21. Crosato, A. Analysis and Modelling of River Meandering. Ph.D. Thesis, Delft University of Technology, Delft, The Netherlands, 2008.

22. Osman, A.M.; Thorne, C.R. Riverbank stability analysis, I: Theory. J. Hydraul. Eng. 1988, 114, $134-150$. [CrossRef]

23. Mosselman, E. Morphological modeling of rivers with erodible banks. Hydrol. Process. 1998, 12, $1357-1370$. [CrossRef]

24. Darby, S.E.; Alabyan, A.M.; Van de Wiel, M.J. Numerical simulation of bank erosion and channel migration in meandering rivers. Water Resour. Res. 2002, 38, 1-21. [CrossRef]

25. Duan, J.G.; Julien, P.Y. Numerical simulation of meandering evolution. J. Hydrol. 2010, 391, 34-46. [CrossRef]

26. Murray, A.B.; Paola, C. A cellular model of braided rivers. Nature 1994, 371, 54-57. [CrossRef]

27. Murray, A.B.; Paola, C. Modelling the effect of vegetation on channel pattern in bedload rivers. Earth Surf. Proc. Land 2003, 2, 131-143. [CrossRef] 
28. Paola, C. Modelling stream braiding over a range of scales. In Gravel Bed Rivers; Mosley, M.P., Ed.; New Zealand Hydrological Society: Wellington, New Zealand, 2001; pp. 111-146.

29. Thormas, R.; Nicholas, A.P. Simulation of braided river flow using a new cellular routing scheme. Geomorphology 2002, 43, 179-196. [CrossRef]

30. Takebayashi, H.; Okabe, T. Numerical modeling of braided streams in unsteady flow. Water Manag. 2009, 162, 189-198.

31. Bridge, J.S.; Lunt, I.A. Depositional models of braided rivers. In Braided Rivers: Process, Deposits, Ecology and Management; Wiley: Hoboken, NJ, USA, 2009.

32. Jang, C.L.; Shimizu, Y. Numerical analysis of braided rivers and alluvial fan deltas. Eng. Appl. Comput. Fluid Mech. 2009, 1, 390-395. [CrossRef]

33. Schuurman, F.; Kleinhans, M. Self-formed braided bar pattern in a numerical model. In River, Coastal and Estuarine Morphodynamics; Springer: Berlin/Heidelberg, Germany, 2011.

34. Lotsari, E.; Wainwright, D.; Corner, G.D.; Alho, P.; Kayhko, J. Surveyed and modeled one-year morphodynamics in the braided lower Tana River. Hydrol. Process. 2014, 28, 2685-2716. [CrossRef]

35. Karmaker, T.; Dutta, S. Prediction of short-term morphological change in large braided river using 2D numerical model. J. Hydraul. Eng. 2016, 142, 04016039. [CrossRef]

36. Crosato, A.; Mosselman, E. Simple physics-based predictor for the number of river bars and the transition between meandering and braiding. Water Resour. Res. 2009, 44, W03424. [CrossRef]

37. Xiao, Y.; Shao, X.J.; Wang, H.; Zhou, H. Formation process of meandering channel by a 2D numerical simulation. Int. J. Sediment. Res. 2012, 3, 306-322. [CrossRef]

38. Xiao, Y.; Yang, S.F.; Su, L. Fluvial sedimentation of the permanent backwater zone in the Three Gorges Reservoir, China. Lake Reserv. Manag. 2015, 31, 324-338. [CrossRef]

39. Ikeda, S.; Izumi, N. Width and depth of self-formed straight gravel rivers with bank vegetation. Water Resour. Res. 1990, 26, 2353-2364. [CrossRef]

40. CWRC. Hydrological data of Changjiang River Basin. Annual Hydrological Report of P. R. China; Changjiang Water Resources Commission: Beijing, China, 2004.

41. Bridge, J.S. The Interaction between Channel Geometry, Water Flow, Sediment Transport and Deposition in Braided Rivers; Geological Society, Special Publications: London, UK, 1993; Volume V75, pp. 13-71.

42. Friend, P.F.; Sinha, R. Braiding and meandering parameters. In Braided Rivers; Best, J.L., Bristow, C.S., Eds.; The Geological Society: London, UK, 1993; pp. 105-112.

43. Henderson, F.M. Stability of alluvial channels. Trans. ASCE 1963, 128, 657-686.

44. Parker, G. Hydraulic geometry of active gravel rivers. J. Hydraul. Div. ASCE 1979, 105, 1185-1201.

45. Millar, R.G. Theoretical regime equations for mobile gravel-bed rivers with stable banks. Geomorphology 2005, 64, 207-220. [CrossRef]

46. Eaton, B.C.; Giles, T.R. Assessing the effect of vegetation-related bank strength on channel morphology and stability in gravel bed streams using numerical models. Earth Surf. Process. Landf. 2009, 34, 712-714. [CrossRef]

(C) 2019 by the authors. Licensee MDPI, Basel, Switzerland. This article is an open access article distributed under the terms and conditions of the Creative Commons Attribution (CC BY) license (http://creativecommons.org/licenses/by/4.0/). 